Misidentification of transthyretin and immunoglobulin variants by proteomics due to methyl lysine formation in formalin-fixed paraffin-embedded amyloid tissue.

Diana Canetti ${ }^{1,2,3}$, Nigel B Rendell ${ }^{1}$, Lucia Di Vagno ${ }^{1}$, Janet A Gilbertson ${ }^{1}$, Dorota Rowczenio $^{1}$, Tamar Rezk ${ }^{1}$, Julian D Gillmore ${ }^{1}$, Phillip N Hawkins ${ }^{1}$, Guglielmo Verona $^{1}$, Palma Patrizia Mangione ${ }^{1,2}$, Sofia Giorgetti ${ }^{2}$, Pierluigi Mauri ${ }^{4}$, Sara Motta ${ }^{4}$, Antonella De Palma ${ }^{4}$, Vittorio Bellotti ${ }^{1,2}$, Graham W Taylor ${ }^{1}$

${ }^{1}$ Wolfson Drug Discovery Unit and National Amyloidosis Centre, Centre for Amyloidosis and Acute Phase Proteins, Division of Medicine, University College London, Royal Free Campus, Rowland Hill Street, London NW3 2PF, UK.

${ }^{2}$ Department of Molecular Medicine, Institute of Biochemistry, University of Pavia, Pavia, Italy.

${ }^{3}$ CEINGE and Department of Chemical Sciences, University of Naples, Naples, Italy. ${ }^{4}$ Proteomics and Metabolomics Laboratory, CNR-ITB, Via Fratelli Cervi, 93, 20090 Segrate (MI), Italy

Corresponding author: Graham W Taylor, Wolfson Drug Discovery Unit, Centre for Amyloidosis and Acute Phase Proteins, Division of Medicine, University College London, Royal Free Campus, Rowland Hill Street, London NW3 2PF, UK. Tel +44 (0)207 433 2805, FAX +44 (0)207 433 2803, graham.taylor@ucl.ac.uk. 


\section{Misidentification of transthyretin and immunoglobulin variants by proteomics due to methyl lysine formation in formalin-fixed paraffin-embedded amyloid tissue}

Proteomics is becoming the de facto gold standard for identifying amyloid proteins, and is now used routinely in a number of centres. The technique is compound-class independent and offers the added ability to identify variant and modified proteins. We re-examined proteomics results from a number of formalin-fixed paraffin-embedded amyloid samples, which were positive for transthyretin (TTR) by immunohistochemistry and proteomics, using the Uniprot human protein database modified to include TTR variants. The amyloidogenic variant, V122I TTR was incorrectly identified in 26/27 wild type and non-V122I variant samples due to its close mass spectral similarity with the methyl lysine modified WT peptide [126K $\left.\mathrm{K}_{\mathrm{Me}}\right] 105-127$ (p.[146 K $\left.\mathrm{K}_{\mathrm{Me}}\right] 125-147$ ) generated during formalin fixation. Similarly, the methyl lysine peptide, $\left[50 \mathrm{~K}_{\mathrm{Me}}\right] 43-59$ from immunoglobulin lambda light chain constant region was also misidentified as arising from a rare myeloma-derived lambda variant V49I. These processingderived modifications are not present in fresh cardiac tissue, non-fixed fat nor serum and do not materially affect the identification of amyloid proteins. They could result in the incorrect assignment of a variant, and this may have consequences for the immediate family who will require genetic counselling and potentially early clinical intervention. As proteomics becomes a routine clinical test for amyloidosis, it becomes important to be aware of potentially confounding issues such as formalin-mediated lysine methylation, and how these may influence diagnosis and possibly treatment.

Keywords: Amyloidosis, formalin, immunoglobulin, proteomics, transthyretin, variant.

Abbreviations. FFPE: formalin-fixed paraffin-embedded; CID: collision induced dissociation; IHC: immunohistochemistry; $\mathrm{K}_{\mathrm{Me}} \mathrm{-WT}$ : methylated wild type; LCMS: liquid chromatography-mass spectrometry; TTR: transthyretin, WT: wild type. 


\section{Introduction}

Amyloidoses are protein misfolding diseases in which normal circulating globular proteins form fibrillar deposits in tissues and organs resulting in structural damage[1]. There are over thirty proteins which form such amyloid deposits and cause the disease [2]. Diagnosis and treatment of patients with amyloidosis is predicated on the correct and accurate identification of the amyloid fibril protein. Classically, immunohistochemistry (IHC), using a range of panel of monospecific antibodies against known amyloid-forming proteins, has been the most common technique available for typing amyloid in formalin-fixed paraffin-embedded (FFPE) tissues [3,4]. The technique is reproducible, but requires experienced staff for both the experimental procedure and the interpretation of the data, and, in up to $30 \%$ of cases IHC fails to confirm the type of amyloid. Other approaches such as immuno-electron microscopy have also shown good specificity and sensitivity in diagnosing amyloidosis [5], although access to equipment and trained operators may not be available in all diagnostic centres. As with all antibody-based approaches, specificity is dependent on the quality and availability of suitable antibodies. The advent of laser dissection of FFPE tissue, coupled with mass spectrometric based proteomic analysis as pioneered by Ahmed Dogan and colleagues at the Mayo Clinic [6-10], has been shown to be a powerful and complementary tool for amyloid identification. The approach is now being applied successfully at a number of other centres [11-17].

Gene mutations, encoding variant proteins, can have a marked effect on the inherent amyloidogenicity of many proteins, and this can lead to the development of amyloidosis. An up-to-date summary of all amyloid protein mutations can be found at http://amyloidosismutations.com/attr.html. Mass spectrometric proteomic approaches are compound-independent, and are ideally suited for the detection and identification of 
variant proteins. This has been recognised by Dasari and colleagues [18] who have developed a proteomics informatics workbench for identifying amyloid variants. There are over 100 point mutations in the transthyretin (TTR) gene resulting in the expression of variant proteins, many of which are more amyloidogenic than the wild type (WT) TTR $[19,20]$. These mutations cause autosomal dominant hereditary systemic ATTR, presenting in adult life as so called familial amyloid polyneuropathy/cardiomyopathy. The clinical phenotype is predominantly one of peripheral and autonomic neuropathy with variable involvement of the heart, kidneys, eyes, and gut. The disease progresses inexorably for 10-15 years and is inevitably fatal.

By far the most common causative mutation encodes the Val30Met substitution and the cases are largely localised to discrete foci in northern Portugal, northern Sweden and specific localities in Japan, as well as the descendants of individuals from these areas living elsewhere [20]. The genetic polymorphism encoding the V122I substitution, is the second most pathogenic polymorphism in African Americans after sickle cell disease and causes cardiac TTR amyloidosis in the elderly [21,22].

Normal WT TTR is inherently amyloidogenic and it has now been demonstrated that cardiac TTR amyloidosis can develop from the WT protein particularly in the elderly. This leads to arrhythmias, heart failure with preserved ejection fraction and death $[23,24]$, conditions which were hitherto commonly attributed to coronary artery disease and other prevalent cardiac conditions. Although, it is not clear what initiates the process of WT TTR amyloid deposition, and we conjectured that the acquisition of low level clones expressing an amyloidogenic variant could act as a source of TTR amyloid seeds. In this study we re-examined proteomic data from a number of TTR amyloid positive FFPE tissues using a modified Uniprot database to include a number of TTR variants: clonal variants were not detected but we observed the presence of $\mathrm{N}$ - 
methylated TTR peptides derived from formalin fixing, and which had been misidentified in the database search as the V122I (p.V142I) variant. Methylated peptides were also observed in biopsies from lambda patients, resulting in incorrect variant assignments, and also in proteins from other FFPE samples.

\section{Methods}

\section{Samples}

Formalin-fixed paraffin-embedded tissue are regularly collected as part of routine diagnostic procedures from patients attending the UK NHS National Amyloidosis Centre and are also received from other centres for immunochemical and proteomics analysis. Thirty five samples of FFPE tissue were randomly selected from patients diagnosed with ATTR amyloidosis and which had been identified as containing TTR amyloid by Congo red staining [25,26], immunohistochemistry using a panel of antibodies, genotyping and proteomics analysis [27,28]. Twenty seven samples were from cardiac tissue, with one sample each of bone marrow, GI tract and penile, two bladder samples and three carpal tunnel samples. The genomic DNA for TTR was sequenced as WT (n=22), V122I (5), T60A (2) and one each of G6S, V20I, V30M, D39V, E89K and H90D. Five non-genotyped TTR samples and twelve non-TTR

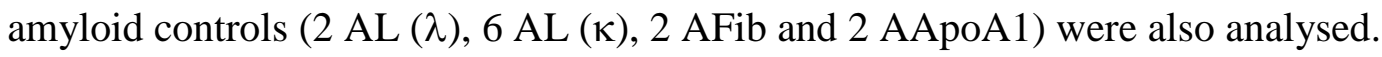
Seven non-formalin-treated fat aspirates from ATTR patients plus six non-ATTR controls, $5 \mathrm{AL}(\lambda)$ and 1 AL $(\kappa)$, together with a four fresh unfixed ATTR cardiac tissue samples, were also obtained as controls for formalin-mediated TTR methylation. In a separate study, designed to investigate the variation in immunoglobulin lambda light chains, a further thirty two FFPE tissues were also collected from seventeen lambda patients and fifteen other non-lambda amyloidosis controls (2 AApoA1, 6 AFib, 4 AL 
(к) and 3 ATTR). Patient data are summarised in Table 1 and supplementary Tables S1 and $\mathrm{S} 2$.

\section{Proteomic analysis}

Amyloid-positive FFPE samples were micro-dissected and captured using the Zeiss Palm Microbeam instrument and were prepared for proteomics analysis using the method of Rodruiguez and colleagues [29]. Similar areas of Congo red positive tissue dissectates $(6 \mu \mathrm{m}$ thick) were extracted into $10 \mathrm{mM}$ Tris in MilliQ water containing $1 \mathrm{mM}$ EDTA and $0.002 \%$ Zwittergen at $99^{\circ} \mathrm{C}$ for 1.5 hours followed by sonication for 1 hour. They were treated with Trypsin Gold $(2.25 \mu \mathrm{g} / \mathrm{sample})$ overnight at $37^{\circ} \mathrm{C}$ and then reduced with dithiothreitol $(50 \mu \mathrm{g})$ at $99^{\circ} \mathrm{C}$ for 5 minutes. The buffer was removed under vacuum and peptides re-suspended in $0.1 \%$ trifluoroacetic acid in water with sonication; any remaining solids were removed by centrifugation $(10,000 \mathrm{~g}$ for 10 minutes). Non-fixed cardiac tissue was divided into two pieces; one piece was fixed and stained with Congo red to confirm the presence of amyloid and the other piece was washed and digested as above. Fat aspirates were washed with PBS and then treated in the same way as FFPE samples; a separate smear was taken to confirm the presence of amyloid. Digests were trapped on a Dionex AcclaimPepMap100 C18 cartridge (5mm x $300 \mu \mathrm{m}$ ID; $5 \mu \mathrm{m}$ particle size, $100 \AA$ A pore size, Thermo Scientific) column and then chromatographed on a packed tip reverse phase column $(100 \mu \mathrm{m}$ ID x $150 \mathrm{~mm}$ bed, 5 $\mu$ m C18 packing; Nikkyo Technos Company Ltd, Tokyo, Japan) using a nanoACQUITY ultraperformance liquid chromatography (UPLC) system (Waters, Elstree, Hertfordshire WD6 3SZ) coupled to a Velos Orbitrap mass spectrometer (Thermo Scientific, Bremen, Germany). Elution was undertaken at 400nl/min with a 44 min linear gradient of acetonitrile:water:formic acid (5:95:0.1 - 60:40:0.1 v/v/v). Optima LCMS grade water, formic acid and trifluoroacetic acid were obtained from 
Fisher Scientific, UK. Chromasolv LC-MS acetonitrile was obtained from Honeywell Research Chemicals, Riedel-de Haën, Germany. The chromatographic system was washed between each sample using a protocol (adapted from Fang [30]) to include separate washes of $10 \%$ formic acid, $0.1 \%$ trifluoroacetic acid, $1 \%$ ammonia in $50 \%$ acetonitrile, $80 \%$ methanol and $80 \%$ acetonitrile in water. A control blank was run prior to each sample to confirm the absence of any carryover. The UPLC eluate was passed directly into the Velos nanospray ion source which was operated in the positive ion mode. A full MS scan (m/z 400-2000) was acquired with a maximum injection time of $50 \mathrm{~ms}$, and the 20 most intense ions with a count threshold $>500$ were selected for collision induced dissociation (CID). The lock mass was set at $\mathrm{m} / \mathrm{z} 445.120024$. The normalised collision energy was 35, with an isolation width of 2 and dynamic exclusion of 20; singly charged ions were excluded. Data were analysed using Mascot software (Matrix Science, London, UK) using the Swissprot human database. Search parameters were: precursor mass tolerance of $10 \mathrm{ppm}, 0.6 \mathrm{Da}$ for collision induced dissociation (CID) fragments, trypsin (and occasionally semi-trypsin) as the proteolytic enzyme, two missed cleavages, included charge states $+2,+3$ and +4 and a significance level at $\mathrm{p}<0.05$. Methionine oxidation, and later $\mathrm{N}$-methyl lysine, were included as variable modifications. A separate Mascot search was then undertaken using a database prepared by appending a selection of variant TTR variants (p.V50M, p.S72P p.T80A, pV142I) or the Kabat [31] immunoglobulin lambda collection (ftp://ftp.ebi.ac.uk/pub/databases/kabat/) to the human Uniprot database. Theoretical CID spectra for manual spectral comparison were generated using Protein Prospector (http://prospector.ucsf.edu/prospector/mshome.htm: UCSF Mass Spectrometry Facility). Three FFPE samples, digested in our laboratory, were also analysed at CNRITB, Milan using a nanoLC platform coupled to a Thermo Q-Exactive mass 
spectrometer with data handling by Proteome Discoverer v 1.4 based on the Sequest algorithm. Sequence numbering will be reported for the mature protein unless otherwise stated. Raw mass spectrometric data are available on request to the corresponding author

\section{Preparation of recombinant V122I TTR}

Recombinant V122I TTR was expressed using a pET3a vector containing the fulllength cDNA for human V122I TTR in E. coli BL21 super competent cells and purified as previously reported [32].

\section{Extraction of TTR from serum}

TTR was immunoprecipitated from serum collected from a V122I patient and from two normal healthy male subjects (age 29 and 64), one of whom had previously been genotyped as WT TTR. A polyclonal affinity-purified sheep anti-human TTR antibody (Binding Site, Birmingham, UK) was buffer-exchanged into PBS using biospin columns (Bio rad laboratories, Herts UK) and incubated overnight at $4^{\circ} \mathrm{C}$ with $\mathrm{CNBR}$ activated sepharose 4B beads (Sigma, prepared following manufacturer's instructions). The beads were then blocked with $0.2 \mathrm{M}$ glycine in PBS and extensively washed with PBS (25ml) followed by 4 x $5 \mathrm{ml}$ washes with $0.1 \mathrm{M}$ acetate buffer in $0.5 \mathrm{M} \mathrm{NaCl}(\mathrm{pH} 4)$ and then 0.1 M sodium bicarbonate buffer in $0.5 \mathrm{M} \mathrm{NaCl}(\mathrm{pH} 8)$; the beads were re-equibrated with 20ml PBS. Serum (100ul) was added to the anti-TTR beads and incubated for 2 hours at room temperature and then washed with PBS (10ml). TTR was eluted from the beads with $200 \mathrm{ul}$ of $0.2 \mathrm{M}$ glycine buffer $\mathrm{pH} 2$. The eluates were neutralised with $1 \mathrm{M}$ Tris $\mathrm{HCl}$ $\mathrm{pH} 8$, dialysed in PBS for 2 days followed by trypsin digestion and proteomics analysis.

\section{Ethical approval}


Samples were collected and analysed as part of routine clinical examination. Informed consent was obtained from all patients and clinical care was in accordance with the Declaration of Helsinki

\section{Results}

\section{Apparent identification of V122I TTR in FFPE tissues}

Thirty five FFPE tissues were selected where transthyretin had been identified as the amyloid protein by immunohistochemistry and proteomics. DNA sequencing identified homozygous WT TTR in the majority of samples, together examples of G6S, V20I, V30M, D39V, T60A, E89K, H90D and V122I variants. Twelve non-TTR control samples were also selected at random: these were $6 \mathrm{AL}(\lambda), 2 \mathrm{AL}(\kappa), 2 \mathrm{AFib}$ and 2 AApoA1 and did not show proteomics evidence for TTR. The proteomics data from each sample was re-analysed using Mascot together with an extended database containing a number of potential TTR variants appended to the Uniprot database. Unexpectedly, both WT TTR and the V122I variant were identified by the presence of the 105-127 (p.125-147) C-terminal fragment in 31/35 samples, including known V122I and non-V122I variants. Other C-terminal fragments including 105-126 were also present in some samples. One sample generated only the WT [122I] 105-127 peptide and was included in further analysis, however three samples failed to show coverage for the residues $105-127$ (encompassing the $122 \mathrm{~V}$ position) and were excluded (Supplementary Table 1), leaving thirty two samples for further analysis (Table 1). It is not uncommon to observe variable protein coverage, due to limited trypsinisation, poor peptide extraction or sample-mediated ion suppression. Even with strongly Congo red positive samples we occasionally observe low or absent amyloid and signature protein scores, even when the total protein recovery is high. The [122I]105-127 variant peptide 
was associated only with TTR amyloid, and was not detected in any of the non-TTR amyloid controls. It is clear, however, that the [122I] peptide cannot arise from the WT protein, implying its presence is artefactual.

\section{Two V122I isobaric peptides identified}

The chromatographic behaviour and mass spectra from each of the thirty two samples, where the 105-127 WT peptide was observed were examined manually: the apparent 122I-containing 107-125 fragment eluted $<5$ s after the equivalent WT peptide [122V]105-127 in the all WT and non-V122I variant samples, generating molecular ion species $\left(\mathrm{MH}_{2}{ }^{2+}, \mathrm{m} / \mathrm{z} 844.94\right)$ and an CID spectrum which was essentially homologous with that from the WT peptide. The amount of this peptide, estimated from relative ion intensities, varied from $0-45.1 \%$ of that of the WT peptide (Table 1). This peptide was also present in 4/5 samples from patients with a confirmed V122I variant, however, in each of these cases, a second peptide was also identified by Mascot as [122I]105-127. It eluted $\sim 30$ s later than the WT peptide (Figure 1), and generated a more intense molecular ion signal which was approximately equi-intense with the corresponding WT peptide. This peptide was only observed in authentic V122I samples. Although the CID mass spectrum appeared similar to that of the earlier eluting component, the different chromatographic retention times showed that these two peptides were structurally dissimilar.

\section{Analysis of recombinant V122I}

Proteomics analysis was then undertaken on authentic recombinant V122I TTR, dissolved either in buffer or in human serum. The characteristic [122I]105-127 peptide eluted $\sim 30$ s after the equivalent WT peptide, [122V]105-127 co-eluting with, and generating indistinguishable mass spectra from, that obtained from both the V122I TTR patients. The earlier eluting $122 \mathrm{~V}$-like component present in the majority of the FFPE 
samples was clearly not the expected variant and appeared to be a $\Delta 14$ homologue of the WT peptide.

\section{Identification of $N$-methyl lysine modified peptides}

Closer examination of the CID spectra of authentic [V122]105-127 peptide and the $\Delta 14$ WT homologue showed that, although the spectra were essentially indistinguishable above m/z 700 (Supplementary Figure S1), there were clear differences at lower masses (Figure 2). Authentic [V122I]105-127 generated y ions at m/z 373.31 (..PKE), 487.31 (...NPKE), 588.40 (...TNPKE) and 701.46 (...ITNPKE) whereas the earlier eluting isomer produced homologues $(\Delta 14 \mathrm{u})$ at $\mathrm{m} / \mathrm{z} 387.46,501.44$ and 602.31 , with $\mathrm{m} / \mathrm{z} 701.46$ common with the V122I ion. These data are consistent with the presence of $\mathrm{N}$-methylated lysine in the WT peptide, YTIAALLSPYSYSTTAVVTNPK $\mathrm{Me}_{\mathrm{E}}$, $\left[126 \mathrm{~K}_{\mathrm{Me}}\right] 105-127$ (Figure 3); here the y series ions > m/z 700 are indistinguishable as ...ITNPKE and ...VTNPK $\mathrm{V}_{\mathrm{Me}} \mathrm{E}(\mathrm{m} / \mathrm{z}$ 701.46), and longer y ion fragments, are isobaric. Homologous b ions for YTIAALLSPYSYSTTAVI.. and YTIAALLSPYSYSTTAVV.. at m/z 1916.0 and 1902.0 arising from V122I and $\mathrm{K}_{\text {Me }}$ peptides respectively were further evidence for the reported sequences. The mass range (m/z 400-2000) of these spectra precluded the identification of other characteristic low and high mass ions.

Re-searching the spectra using the TTR variant database with Mascot using methyl lysine as a variable modification identified [126KMe $] 105-127$ in $26 / 27$ nonV122I samples, with retention times similar to that of the non-methylated WT peptide. In only one case was the $\mathrm{K}_{\mathrm{Me}}$-WT peptide below detection in the selected ion mass chromatogram. Both the $\left[126 \mathrm{~K}_{\mathrm{Me}}\right]$ WT TTR and V122I TTR were identified in the five samples from V122I patients, including one (patient 10), where the methylated peptide wasn't detected by LCMS. There were 28 positive Mascot queries for $\mathrm{K}_{\mathrm{Me}}-\mathrm{WT}$ and V122I in this group, however, many of the same queries, with different peptide scores, 
were used for both sets of identities: $\mathrm{K}_{\mathrm{Me}}-\mathrm{WT}$ was identified in only one sample, V122I in 8 samples, with both proteins identified in 19 samples. The retention times associated with these 19 scored peptides covered both the methylated and variant peptide region and were insufficient to allow differentiation; only the retention times determined from the LCMS selected ion chromatograms allowed confirmation of the presence of $\mathrm{KMe}^{-}$ WT and V122I TTR in these samples. The corresponding 122I methylated peptide could also be detected in $3 / 5$ samples, eluting $\sim 0.4 \mathrm{~s}$ later than the 122I peptide. Other methylated TTR peptides (35-48, 49-70 and 49-76) were present in some samples together with methylated proteins including the amyloid signature protein, serum amyloid P component. Analysis of non-TTR FFPE control samples also showed the presence of $\mathrm{N}$-methylated proteins, including Ig lambda, however this seemed to be more variable with no evidence of methylation in some cases.

\section{Analysis of fresh tissue}

Data from thirteen non-formalin treated fat aspirates obtained in our clinic and a four fresh ATTR cardiac tissue samples were also re-analysed for the presence of methyl lysine peptides. There was no evidence for lysine methylation in either the amyloid or amyloid signature proteins in any of these samples, nor, indeed in any other proteins apart from some occasional low scoring $(<10)$ queries ascribed to haemoglobin peptides. Three TTR-positive fat samples did not show coverage of the 105-127 region and were then excluded from further analysis. The authentic variant [122I]105-127 peptide was identified both from its retention time, eluting $27 \mathrm{~s}$ after the WT peptide, and its CID mass spectrum in the single fat sample from a V122I patient.

To confirm that $\left[126 \mathrm{~K}_{\mathrm{Me}}\right] 105-127$ peptide was not derived from a circulating methylated protein, TTR was extracted by immunoprecipitation from serum from a 
genotyped WT patient and two healthy controls. In each case only WT TTR was identified with no evidence for $\left[126 \mathrm{~K}_{\mathrm{Me}}\right] 105-127$ or other methylated peptides

These data indicated that the V122I variant, apparently present in most of the FFPE samples examined, had been misidentified due to the close spectral similarity with the $\left[126 \mathrm{~K}_{\mathrm{Me}}\right]$ homologue of the WT peptide [V122]105-127. Zhang and colleagues [33] have recently shown that formalin fixing can cause lysine methylation, and our data is entirely consistent with their report.

\section{Immunoglobulin light chain lysine methylation}

The presence of immunoglobulin light chain peptides in non-AL amyloidosis patient samples is not uncommon [34], and in an unrelated study we were examining ways to increase confidence in the proteomics of AL amyloidosis samples by appending the Kabat collection of lambda and kappa light chain sequences to the Uniprot human database. In many cases of light chain amyloid, extra variable region peptides could be identified and this was helpful in confirming the amyloid type. Using this extended database we noted that a $\Delta 14$ peptide, ADSSPIKAGVETTTPSK, corresponding to an uncommon $\mathrm{I} \rightarrow \mathrm{V}$ variant at residue 49 of the lambda constant region ([49I]44-60) from a human myeloma cryoglobulin [35] could be identified by Mascot in 11/17 AL ( $\lambda)$ patient samples and also in 2/15 non-AL $(\lambda)$ controls (supplementary Table S2) where lambda was a significant contaminant. The structure of this variant is identical with the Lac2 lambda constant region but lacks the N-terminal glycine at the junction with the variable region; for reasons of clarity the WT numbering is used. The presence of [49I]44-60 was unexpected as this region is not normally detected in the WT protein since there is a facile tryptic cleavage at K50 generating two small peptides outwith the normal acquisition mass range of our instrument. Initially we considered whether low level clonal production of the myeloma protein was responsible for seeding lambda 
deposition, however, based on our experience with formalin-modified TTR we reexamined the data for the samples originally identified as the lambda variant using Nmethyl lysine as a variable modification in a Swissprot database search. All were identified as containing the lambda (Lac2) constant region methylated peptide, [50K $\left.\mathrm{Ke}_{\mathrm{Me}}\right] 44-60$ together with other lambda methyl lysine peptides, notably 22-43, 66-80 and 84-98. A number of methyl lysine containing peptides arising from nonamyloidogenic proteins were also identified. Differentiation between the $50 \mathrm{~K}_{\mathrm{Me}}$ and $49 \mathrm{I}$ peptides is difficult since their CID spectra are very closely related with only two characteristic b6 and y7 ions, $\mathrm{m} / \mathrm{z}$ 557.257, 1132.621 and m/z 571.272, 1118.605 respectively, distinguishing the two peptides. There was no evidence for either of the characteristic 49I ions in any of the spectra. In contrast, $\left[50 \mathrm{~K}_{\mathrm{Me}}\right] 44-60$ was confirmed in 6/15 samples by the presence of one or both of its characteristic ions (Figure 4). In the remaining samples there was no ion coverage for the $49 \mathrm{I} / 50 \mathrm{~K}_{\mathrm{Me}}$ region in the mass spectra and it was therefore not possible to differentiate between the putative variant and the methylated WT peptide. However, since trypsin cleavage at methyl lysine is slow, and a simple $\mathrm{V} \rightarrow \mathrm{I}$ change would not be expected to alter sensitivity of a peptide to trypsin, the presence of the methylated $\left[50 \mathrm{~K}_{\mathrm{Me}}\right] 44-60$ is far more likely than the equivalent variant [49I]44-60 peptide with an internal unmodified lysine. Indeed, the cleavage after $50 \mathrm{~K}$ in wildtype lambda is facile that it is rare to see coverage of this region. These data are fully consistent with the conclusion that the $\Delta 14$ peptide originally identified as a 49I variant in lambda samples was actually the formalinderived $50 \mathrm{~K}_{\mathrm{Me}} \mathrm{WT}$ product. Protein coverage for a lambda sample as determined by a Mascot search using Swissprot (with and without methyl lysine as a variable modification) or Kabat database is shown in Figure 5. 
Not all of the lambda samples were originally identified as containing the variant/ $\mathrm{K}_{\mathrm{Me}}$ peptides suggesting that the amount of formalin-mediated methylation is variable and differs from sample to sample, and possibly even within an individual biopsy. A further set of 12 lambda samples, individually dissected from a single biopsy over a period of 12 months were examined for the presence of the variant $/ \mathrm{K}_{\mathrm{Me}}$ peptide. All were positive for $50 \mathrm{~K}_{\mathrm{Me}}$ peptide based on the molecular mass and partial sequence. Manual examination of the spectra gave no evidence for any 49I characteristic ions, although was only possible to confirm the presence of $50 \mathrm{~K}_{\mathrm{Me}}$ in one sample through the presence of its characteristic CID ions. Three of these digested samples were then analysed at CNR-ITB, Milan using a Thermo Q-Exactive platform; each showed evidence for $\mathrm{m} / \mathrm{z} 1132.63$ with partial sequence ...K $\mathrm{K}_{\mathrm{Me}} \mathrm{AGVETTTPS} \ldots .$. (Supplementary Figure S2) confirming our initial identification.

These data on samples of immunoglobulin lambda light chain amyloid are further evidence that the formalin fixing of human biopsies taken for clinical purposes results in the formation of $\mathrm{N}$-methyl lysine, and that this can lead to the misidentification of a variant.

\section{Discussion}

Over the past four years we have used the proteomics approach developed at the Mayo Clinic and have examined over 1500 FFPE samples from both patients attending our clinics and also referred biopsy samples. Our general experience is that proteomics complements, but does not always supplant, immunohistochemical analysis. Our 2015 audit showed $70 \%$ concordance between the proteomics and immunohistochemistry data. Mass spectrometric approaches are not limited by compound class, and this is particularly beneficial when identifying variant proteins [36]. There are numerous 
mutations associated with the genes for the amyloidogenic proteins, in particular with ApoA1, transthyretin and fibrinogen $A \alpha$, many of which result in the expression of variant amyloidogenic proteins and consequent different clinical presentations. For example, the most common form of familial amyloid polyneuropathy is caused by the V30M TTR whereas the V122I variant, which is common in African Americans causes cardiac ATTR amyloidosis in the elderly. In contrast, the T119M mutation appears to confer protection against TTR amyloidosis. There is clearly some clinical benefit in identifying these variants as part of a routine proteomics approach [18].

When we re-examined the proteomics data from FFPE biopsies from patients diagnosed with TTR amyloidosis using our variant database, it was surprising to find that V122I TTR was identified in so many samples, and it soon became clear that this was a false identification. Manual examination of the mass spectra indicated the presence of a methyl lysine homologue of the WT peptide 105-127. The chromatographic retention times and mass spectra were consistent with the presence of $\left[126 \mathrm{~K}_{\mathrm{Me}}\right] 105-127$ and not [122I]105-127 in these samples, and this was confirmed by a subsequent Mascot search including methyl lysine as a variable modification. The absence of $\left[126 \mathrm{~K}_{\mathrm{Me}}\right] 105-127$ in unfixed tissue, fat aspirates and serum was consistent with its generation by formalin fixing. We also observed methylated derivatives of SAP and a range of other proteins in FFPE tissue, so this effect was not limited to the amyloidogenic protein. We were aware of the range of modifications which can arise through formalin fixation [37,38], however, it was only following the report by Zhang and colleagues [33] that it became clear that lysine methylation was a major modification induced by FFPE tissue processing. They cautioned this could skew the results when studying biological methylations: clearly it can potentially affect clinical diagnosis as well. The amount of $\left[126 \mathrm{~K}_{\mathrm{Me}}\right] 105-127$ in different samples varied from 0 - 
$45.1 \%$ of the WT protein and this was irrespective of tissue source, although we note that this is an estimate based on ion channel intensities and assumes an equivalent ionisation efficiency. We receive FFPE tissues from a number of hospitals throughout the world, and so it is not possible to account for, or indeed control, the conditions under which samples are fixed, and consequently the amount of N-methylation that can occur. Similarly with the lambda samples, the identification of an obscure variant in the constant chain was not expected, and the presence of a methyl lysine was postulated. In most cases it was not possible to distinguish the $49 \mathrm{I}$ and $50 \mathrm{~K}_{\mathrm{Me}}$ peptides. The absence of any mass spectra unequivocally defining [491]53-59 and the clear identification of the $50 \mathrm{~K}_{\mathrm{Me}}$ peptide in a few samples strongly suggests that formalin-mediated methylation has occurred. Our mass spectrometric data were generated on a Velos Orbitrap. High energy collision spectra, obtained on a different platform, the Q-Exactive Orbitrap machine, in collaboration with colleagues at CNR-ITB, Milan, allowed us to more easily distinguish between the spectra of the two $\Delta 14$ lambda peptides and confirm the presence of N-methylated peptides.

In a recent review covering the progress and potential of proteomics in cardiac amyloidosis, Lavatelli and Merlini [39] quite correctly stated that "amyloidogenic mutations can be confirmed if the variant peptide is visible and the variant sequence is deposited in the sequence repositories"; it is, of course, a pre-requisite that the variant peptide can be unambiguously identified. We normally use Mascot, and less commonly Scaffold/X! Tandem, as our preferred search engine, although others recommend multiple engines to enhance protein identification both generally $[40,41]$ and in particular for amyloid identification [6]. The close proximity of a methylated lysine to an apparent $\Delta 14$ variant such as $\mathrm{V} \rightarrow \mathrm{I}$ (as in these samples), or for example, $\mathrm{G} \rightarrow \mathrm{A}$, will always result in an identical parent ion mass and very similar CID fragment ions. There 
is no reason to believe that other search engines or a combination of search methods would have eliminated the problem of misidentifying FFPE methylation products as variants. As the separation in the peptide between the methylated lysine and apparent $\Delta 14$ variant increases then it becomes easier to distinguish between the CID spectra, and there is less chance of misidentification.

Once the effects of formalin fixation are recognised, it is simple to include methyl lysine or other derivatives as a variable in the search. Since the methylated WT and V122I variant peptides are chromatographically distinct, LCMS retention times obtained could be used to increase confidence in the structural assignments. Although retention times for each scored peptide are available in search outputs, the values associated with $\mathrm{K}_{\mathrm{Me}}-\mathrm{WT}$ and V122I peptides were similar and it was not possible to differentiate these peptides without directly examining the raw LCMS ion chromatograms. The effects of formalin would not be an issue if unfixed tissue were to be used, however this is not normally collected for routine clinical diagnostics, particularly if samples are to be sent to a separate referral lab for analysis. Serum has been examined for amyloid precursors, for example to characterise free light chains $[42,43]$ and fresh fat aspirates are now routinely available for proteomics analysis $[44,45]$, although both will always be a surrogate for identifying amyloid deposition in the target tissue and may fail to identify cases where two distinct types of amyloid are present in the same tissue $[12,46]$.

Does the misidentification of variants matter clinically? At one level, it doesn't: AL amyloidosis will be treated with chemotherapy irrespective of the potential presence of a rare constant region variant. Of course, should $\mathrm{N}$-methylation also occur in the light chain variable region, then misidentification could compromise the identification of light chain clones [47]. Current treatments for ATTR amyloidosis with diflunisal or 
tafamidis will still be used for many ATTR patients, however the identification of an aggressive variant will affect the prognosis and may suggest liver transplant as an option. It could also have consequences for the patient's immediate family where genetic counselling and potentially early clinical intervention may be incorrectly indicated. Further, recent studies on the mechanism of TTR fibrillogenesis initiated by proteolytic cleavage [48] have indicated that ligand-mediated inhibition differs for each variant; it may therefore important to correctly identify the variant when determining a suitable therapeutic dose.

The potential problems with using proteomics as the sole method for amyloid typing have also been recognised by Brown and colleagues [49]. In a study on ATTR amyloidosis they noted that "LC-MS/MS is not sufficient to rule out a pathogenic mutation in cases of ATTR amyloid, and genetic testing should be performed in most cases". We would not disagree: to extend the three legged stool' analogy (attributed to Richard Hooker), we would argue that the most robust diagnosis of amyloidosis relies on the three legs of clinical experience, biochemistry (Congo red staining, IHC and genetic analysis) and proteomics. Even then, as proteomics becomes a routine clinical test and we begin to rely entirely on the output from increasingly complex search engine algorithms, it becomes important to be aware of how unanticipated effects such as FFPE-mediated methylation can result in variant misidentification and influence diagnosis and possibly treatment.

\section{Acknowledgments}

Core support for the Wolfson Drug Discovery Unit is provided by the UK National Institute for Health Research Biomedical Research Centre and Unit Funding Scheme. The NHS National Amyloidosis Centre is commissioned by NHS Highly Specialised Services. We thank Professor Piero Pucci (University of Naples) and Dr John Cottrell 
(Matrix Science Ltd) for helpful discussions and Ms Yiwei Guan for translating and commenting on reference 13 .

\section{Authors' declaration of interests}

The authors declare that they have no conflicts of interest.

\section{References}

1. Pepys MB. Amyloidosis. Annual review of medicine 2006;57:223-41.

2. Sipe JD, Benson MD, Buxbaum JN, Ikeda SI, Merlini G, Saraiva MJ, Westermark P. Amyloid fibril proteins and amyloidosis: chemical identification and clinical classification International Society of Amyloidosis 2016 Nomenclature Guidelines. Amyloid : the international journal of experimental and clinical investigation : the official journal of the International Society of Amyloidosis 2016;23:209-13.

3. Schonland SO, Hegenbart U, Bochtler T, Mangatter A, Hansberg M, Ho AD, Lohse P, et al. Immunohistochemistry in the classification of systemic forms of amyloidosis: a systematic investigation of 117 patients. Blood 2012;119:488-93.

4. Linke RP. On typing amyloidosis using immunohistochemistry. Detailed illustrations, review and a note on mass spectrometry. Progress in histochemistry and cytochemistry 2012;47:61-132.

5. Fernandez de Larrea C, Verga L, Morbini P, Klersy C, Lavatelli F, Foli A, Obici L, et al. A practical approach to the diagnosis of systemic amyloidoses. Blood 2015;125:2239-44.

6. Vrana JA, Gamez JD, Madden BJ, Theis JD, Bergen HR, 3rd, Dogan A. Classification of amyloidosis by laser microdissection and mass spectrometry-based proteomic analysis in clinical biopsy specimens. Blood 2009;114:4957-9.

7. D'Souza A, Theis J, Quint P, Kyle R, Gertz M, Zeldenrust S, Vrana J, et al. Exploring the amyloid proteome in immunoglobulin-derived lymph node amyloidosis using laser microdissection/tandem mass spectrometry. American journal of hematology 2013;88:57780.

8. Dogan A. Amyloidosis: Insights from Proteomics. Annual review of pathology 2017;12:277-304.

9. Theis JD, Dasari S, Vrana JA, Kurtin PJ, Dogan A. Shotgun-proteomics-based clinical testing for diagnosis and classification of amyloidosis. Journal of mass spectrometry : JMS 2013;48:1067-77.

10. Mereuta OM, Theis JD, Vrana JA, Law ME, Grogg KL, Dasari S, Chandan VS, et al. Leukocyte cell-derived chemotaxin 2 (LECT2)-associated amyloidosis is a frequent cause of hepatic amyloidosis in the United States. Blood 2014;123:1479-82.

11. Brambilla F, Lavatelli F, Merlini G, Mauri P. Clinical proteomics for diagnosis and typing of systemic amyloidoses. Proteomics Clinical applications 2013;7:136-43.

12. Mahmood S, Gilbertson JA, Rendell N, Whelan CJ, Lachmann HJ, Wechalekar AD, Hawkins PN, et al. Two types of amyloid in a single heart. Blood 2014;124:3025-7.

13. Shen K, Sun W, Sun J, Sun W, Zhong D, Cao X, Zhou D, et al. [Classification of amyloidosis by laser micro-dissection and mass spectrometry based proteomic analysis]. Zhonghua xue ye xue za zhi = Zhonghua xueyexue zazhi 2015;36:99-102.

14. Azevedo EP, Pereira HM, Garratt RC, Kelly JW, Foguel D, Palhano FL. Dissecting the structure, thermodynamic stability, and aggregation properties of the A25T transthyretin (A25T-TTR) variant involved in leptomeningeal amyloidosis: identifying protein partners that co-aggregate during A25T-TTR fibrillogenesis in cerebrospinal fluid. Biochemistry 2011;50:11070-83. 
15. Ramirez-Alvarado M, Barnidge DR, Murray DL, Dispenzieri A, Marin-Argany M, Dick CJ, Cooper SA, et al. Assessment of renal response with urinary exosomes in patients with AL amyloidosis: A proof of concept. American journal of hematology 2017;92:536-41.

16. Mollee P, Boros S, Loo D, Ruelcke JE, Lakis VA, Cao KL, Renaut P, et al. Implementation and evaluation of amyloidosis subtyping by laser-capture microdissection and tandem mass spectrometry. Clinical proteomics 2016;13:30.

17. Yoshinaga T, Yazaki M, Kametani F, Sekijima Y, Iesato Y, Miyahara T, Tsuchiya-Suzuki A, et al. Marked biochemical difference in amyloid proportion between intra- and extraocular tissues in a liver-transplanted patient with hereditary ATTR amyloidosis. Amyloid : the international journal of experimental and clinical investigation : the official journal of the International Society of Amyloidosis 2017;24:17-23.

18. Dasari S, Theis JD, Vrana JA, Zenka RM, Zimmermann MT, Kocher JP, Highsmith WE, Jr., et al. Clinical proteome informatics workbench detects pathogenic mutations in hereditary amyloidoses. Journal of proteome research 2014;13:2352-8.

19. Connors LH, Lim A, Prokaeva T, Roskens VA, Costello CE. Tabulation of human transthyretin (TTR) variants, 2003. Amyloid : the international journal of experimental and clinical investigation : the official journal of the International Society of Amyloidosis 2003;10:160-84.

20. Plante-Bordeneuve V, Said G. Familial amyloid polyneuropathy. The Lancet Neurology 2011;10:1086-97.

21. Buxbaum JN, Ruberg FL. Transthyretin V122I (pV142I)* cardiac amyloidosis: an agedependent autosomal dominant cardiomyopathy too common to be overlooked as a cause of significant heart disease in elderly African Americans. Genetics in medicine : official journal of the American College of Medical Genetics 2017.

22. Quarta CC, Buxbaum JN, Shah AM, Falk RH, Claggett B, Kitzman DW, Mosley TH, et al. The amyloidogenic V122I transthyretin variant in elderly black Americans. The New England journal of medicine 2015;372:21-9.

23. Westermark P, Sletten K, Johansson B, Cornwell GG, 3rd. Fibril in senile systemic amyloidosis is derived from normal transthyretin. Proceedings of the National Academy of Sciences of the United States of America 1990;87:2843-5.

24. Mohammed SF, Mirzoyev SA, Edwards WD, Dogan A, Grogan DR, Dunlay SM, Roger VL, et al. Left ventricular amyloid deposition in patients with heart failure and preserved ejection fraction. JACC Heart failure 2014;2:113-22.

25. Puchtler H, Sweat F. Congo red as a stain for fluorescence microscopy of amyloid. The journal of histochemistry and cytochemistry : official journal of the Histochemistry Society 1965;13:693-4.

26. Puchtler H, Waldrop FS, Meloan SN. A review of light, polarization and fluorescence microscopic methods for amyloid. Applied pathology 1985;3:5-17.

27. Gilbertson JAH, T.; Hawkins, P.N. Amyloid typing: experience from a large referral centre. In: Amyloid and related disorders Humana Press 2012:231-8.

28. Gilbertson JA, Theis JD, Vrana JA, Lachmann H, Wechalekar A, Whelan C, Hawkins PN, et al. A comparison of immunohistochemistry and mass spectrometry for determining the amyloid fibril protein from formalin-fixed biopsy tissue. Journal of clinical pathology 2015;68:314-7.

29. Rodriguez FJ, Gamez JD, Vrana JA, Theis JD, Giannini C, Scheithauer BW, Parisi JE, et al. Immunoglobulin derived depositions in the nervous system: novel mass spectrometry application for protein characterization in formalin-fixed tissues. Laboratory investigation; a journal of technical methods and pathology 2008;88:1024-37.

30. Fang J, Rand KD, Beuning PJ, Engen JR. False EX1 signatures caused by sample carryover during HX MS analyses. International journal of mass spectrometry 2011;302:19-25.

31. Wu TT, Kabat EA. An analysis of the sequences of the variable regions of Bence Jones proteins and myeloma light chains and their implications for antibody complementarity. The Journal of experimental medicine 1970;132:211-50. 
32. Verona G, Mangione PP, Raimondi S, Giorgetti S, Faravelli G, Porcari R, Corazza A, et al. Inhibition of the mechano-enzymatic amyloidogenesis of transthyretin: role of ligand affinity, binding cooperativity and occupancy of the inner channel. Scientific reports 2017;7:182.

33. Zhang Y, Muller M, Xu B, Yoshida Y, Horlacher O, Nikitin F, Garessus S, et al. Unrestricted modification search reveals lysine methylation as major modification induced by tissue formalin fixation and paraffin embedding. Proteomics 2015;15:2568-79.

34. Mangione PP, Mazza G, Gilbertson JA, Rendell NB, Canetti D, Giorgetti S, Frenguelli L, et al. Increasing the accuracy of proteomic typing by decellularisation of amyloid tissue biopsies. Journal of proteomics 2017.

35. Lopez de Castro JA, Chiu YY, Poljak RJ. Amino acid sequence of the variable region of the light (lambda) chain from human myeloma cryoimmunoglobulin IgG Hil. Biochemistry 1978; 17:1718-23.

36. Nasr SH, Dasari S, Mills JR, Theis JD, Zimmermann MT, Fonseca R, Vrana JA, et al. Hereditary Lysozyme Amyloidosis Variant p.Leu102Ser Associates with Unique Phenotype. Journal of the American Society of Nephrology : JASN 2017;28:431-8.

37. Metz B, Kersten GF, Hoogerhout P, Brugghe HF, Timmermans HA, de Jong A, Meiring H, et al. Identification of formaldehyde-induced modifications in proteins: reactions with model peptides. The Journal of biological chemistry 2004;279:6235-43.

38. Hood BL, Conrads TP, Veenstra TD. Mass spectrometric analysis of formalin-fixed paraffin-embedded tissue: unlocking the proteome within. Proteomics 2006;6:4106-14.

39. Lavatelli F, Merlini G. Advances in proteomic study of cardiac amyloidosis: progress and potential. Expert review of proteomics 2016:1-11.

40. Shteynberg D, Nesvizhskii AI, Moritz RL, Deutsch EW. Combining results of multiple search engines in proteomics. Molecular \& cellular proteomics : MCP 2013;12:2383-93.

41. Yuan ZF, Lin S, Molden RC, Garcia BA. Evaluation of proteomic search engines for the analysis of histone modifications. Journal of proteome research 2014;13:4470-8.

42. Barnidge DR, Dasari S, Botz CM, Murray DH, Snyder MR, Katzmann JA, Dispenzieri A, et al. Using mass spectrometry to monitor monoclonal immunoglobulins in patients with a monoclonal gammopathy. Journal of proteome research 2014;13:1419-27.

43. Lavatelli F, Brambilla F, Valentini V, Rognoni P, Casarini S, Di Silvestre D, Perfetti V, et al. A novel approach for the purification and proteomic analysis of pathogenic immunoglobulin free light chains from serum. Biochimica et biophysica acta 2011;1814:409-19.

44. Vrana JA, Theis JD, Dasari S, Mereuta OM, Dispenzieri A, Zeldenrust SR, Gertz MA, et al. Clinical diagnosis and typing of systemic amyloidosis in subcutaneous fat aspirates by mass spectrometry-based proteomics. Haematologica 2014;99:1239-47.

45. Brambilla F, Lavatelli F, Di Silvestre D, Valentini V, Rossi R, Palladini G, Obici L, et al. Reliable typing of systemic amyloidoses through proteomic analysis of subcutaneous adipose tissue. Blood 2012;119:1844-7.

46. Godecke VA, Rocken C, Steinmuller-Magin L, Nadrowitz F, Fleig SV, Haller H, Wagner AD. Mixed leukocyte cell-derived chemotaxin 2 and amyloid A renal amyloidosis in a Kazakh-German patient. Clinical kidney journal 2017;10:266-8.

47. Dasari S, Theis JD, Vrana JA, Meureta OM, Quint PS, Muppa P, Zenka RM, et al. Proteomic detection of immunoglobulin light chain variable region peptides from amyloidosis patient biopsies. Journal of proteome research 2015;14:1957-67.

48. Marcoux J, Mangione PP, Porcari R, Degiacomi MT, Verona G, Taylor GW, Giorgetti S, et al. A novel mechano-enzymatic cleavage mechanism underlies transthyretin amyloidogenesis. EMBO molecular medicine 2015;7:1337-49.

49. Brown EE, Lee YZJ, Halushka MK, Steenbergen C, Johnson NM, Almansa J, Tedford RJ, et al. Genetic testing improves identification of transthyretin amyloid (ATTR) subtype in cardiac amyloidosis. Amyloid : the international journal of experimental and clinical investigation : the official journal of the International Society of Amyloidosis 2017:1-4. 
Table 1. ATTR patients' sample details showing the relative amount of the formalin-derived $\mathrm{K}_{\mathrm{Me}}-\mathrm{WT}$ 105-127 peptide and the 122I variant peptide.

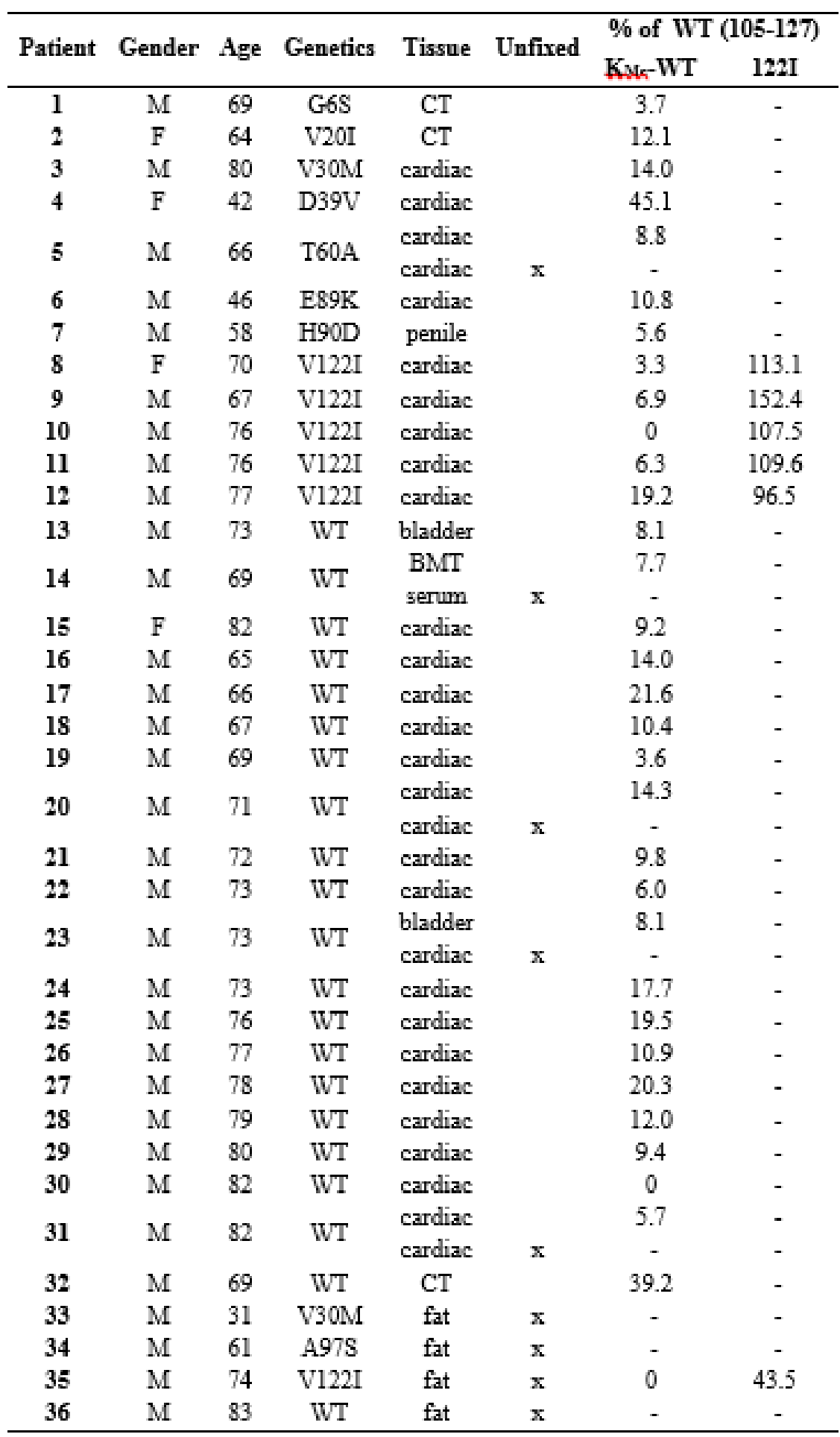

CT: carpal tunnel, BMT: bone marrow trephine. 
Figure 1. Selected ion chromatograms for TTR peptide 105-127 from patients with WT TTR (2, panel A) or heterozygous WT/V122I TTR (12, panel B). Ion channels are shown for $\mathrm{MH}_{2}{ }^{2+} \mathrm{m} / \mathrm{z}$ 1245.14, corresponding to the WT peptide (A1 and B1), and also for the $\mathrm{MH}_{2}{ }^{2+} \mathrm{m} / \mathrm{z} 1252.15$ which is isobaric for the $\mathrm{N}$-methylated WT peptide, $\left[126 \mathrm{~K}_{\mathrm{Me}}\right] 105-127$ (A2) and the 122I variant peptide (B2). In the patient expressing WT TTR only, the methylated derivative was present and eluted $<5 \mathrm{~s}$ after the WT peptide, although the intensity was lower. This peptide was also observed in 4/5 of the nonV122I patient samples. Authentic [122I]105-127 from patient B eluted 30s after the WT peptide at $30.6 \mathrm{~min}$, with a similar intensity (B2). It had the same retention time as the peptide generated from authentic recombinant V122I TTR. There was a small amount of the methylated WT peptide also present. Ion channels in patients A and B were smoothed and normalised to the maximum wave image current within the retention time window of 249,674 and 49, 939 respectively.

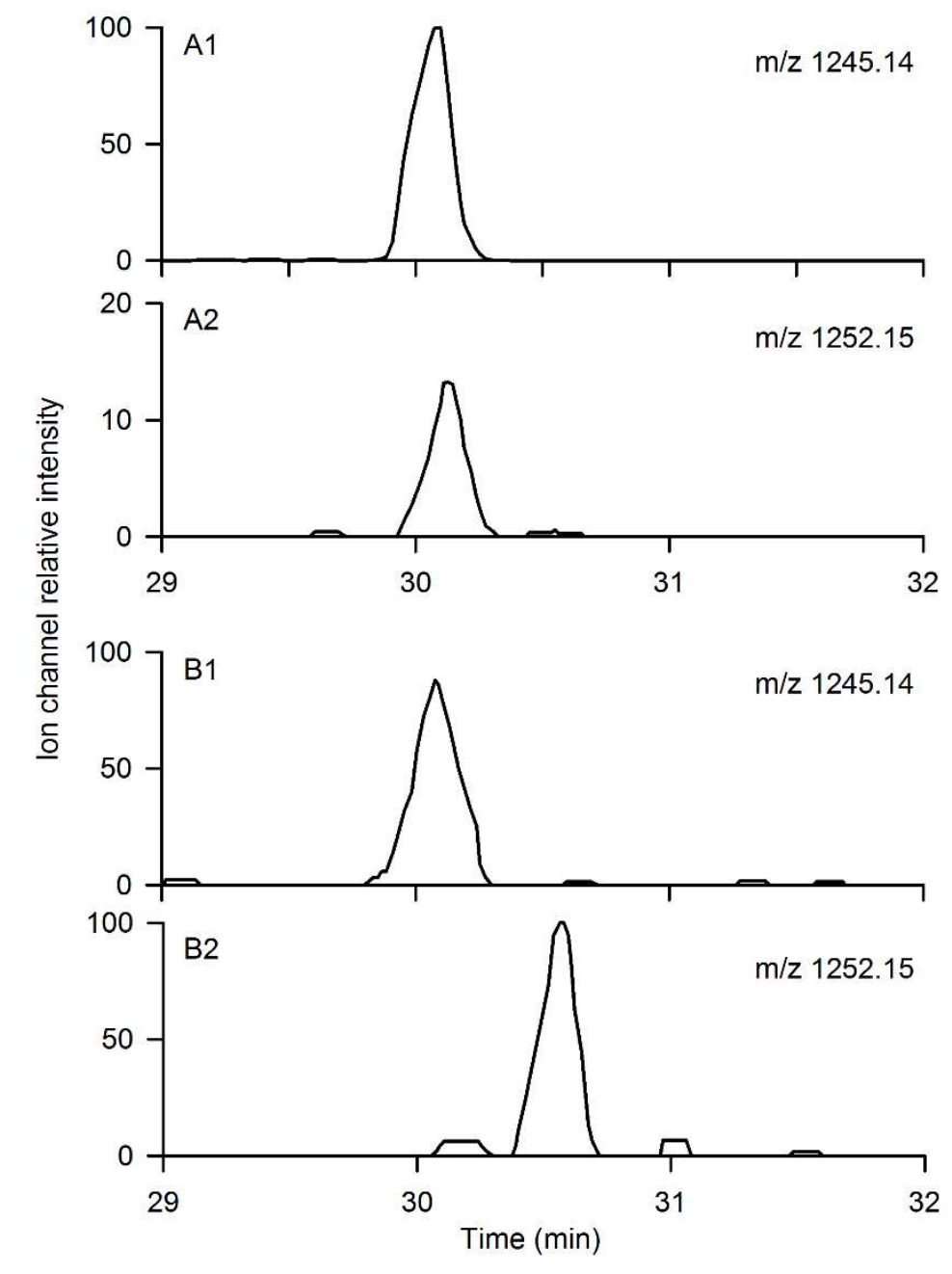


Figure 2. Collision induced mass spectrum for 122I[105-127] from a patient confirmed to exhibit the V122I mutation (A). This peptide eluted $\sim 30$ s after the corresponding WT peptide with a mass spectrum which was indistinguishable from that obtained from recombinant V122I TTR. In samples from non-V122I patients the $\Delta 14$ 105-127 peptide eluted $<5 \mathrm{~s}$ after the WT peptide and generated a similar CID mass spectrum (B), differing from V122I[105-127] at ion masses below $\mathrm{m} / \mathrm{z}$ 700. The characteristic y ions which distinguish the two isobaric peptides are highlighted (*).

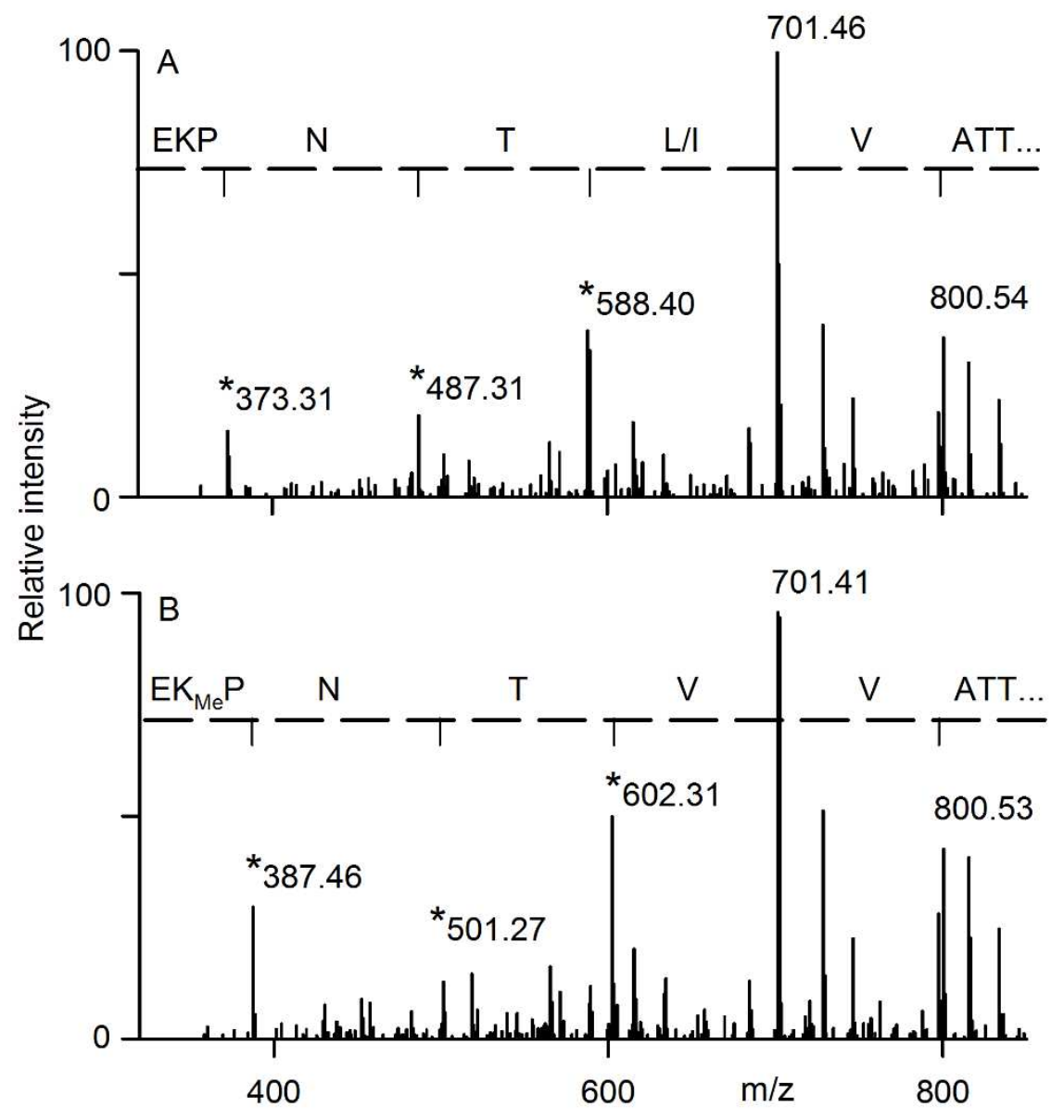


Figure 3. Alignment of peptide 105-127 for WT TTR, V122I TTR and $126 \mathrm{~K}_{\mathrm{Me}} \mathrm{WT}$ TTR. The positions of the variant and methylated lysine are arrowed.

$$
\begin{aligned}
& \text { WT TTR } \text { TR5-127 }_{10(R) \text { YTIAALLSPYSYSTTAVVTNPKE }} \\
& \text { V122I TTR } 105-127 \ldots(R) \text { YTIAALLSPYSYSTTAVITNPKE } \\
& \mathrm{K}_{\text {Me }} \text { WT TTR } \text { TTR }_{105-127} \ldots(\mathrm{R}) \text { YTIAALLSPYSYSTTAVVTNPK } \mathrm{Me}_{\text {E }} \\
& \uparrow \uparrow
\end{aligned}
$$


Figure 4. Collision induced dissociation mass spectrum of methylated lambda light chain constant region generated from the molecular ion species, $\mathrm{MH}_{2}{ }^{2+} \mathrm{m} / \mathrm{z} 844.94$ (A). The most intense $b$ and $y$ ions for the peptide are labelled*. Expanded regions for the characteristic b6 (m/z 557.260 and y11 (m/z 1132.62) ions are shown in panel B, and confirm the presence of the methylated peptide $\left[50 \mathrm{~K}_{\mathrm{Me}}\right] 44-60$ and the absence of the $49 \mathrm{I}$ variant.
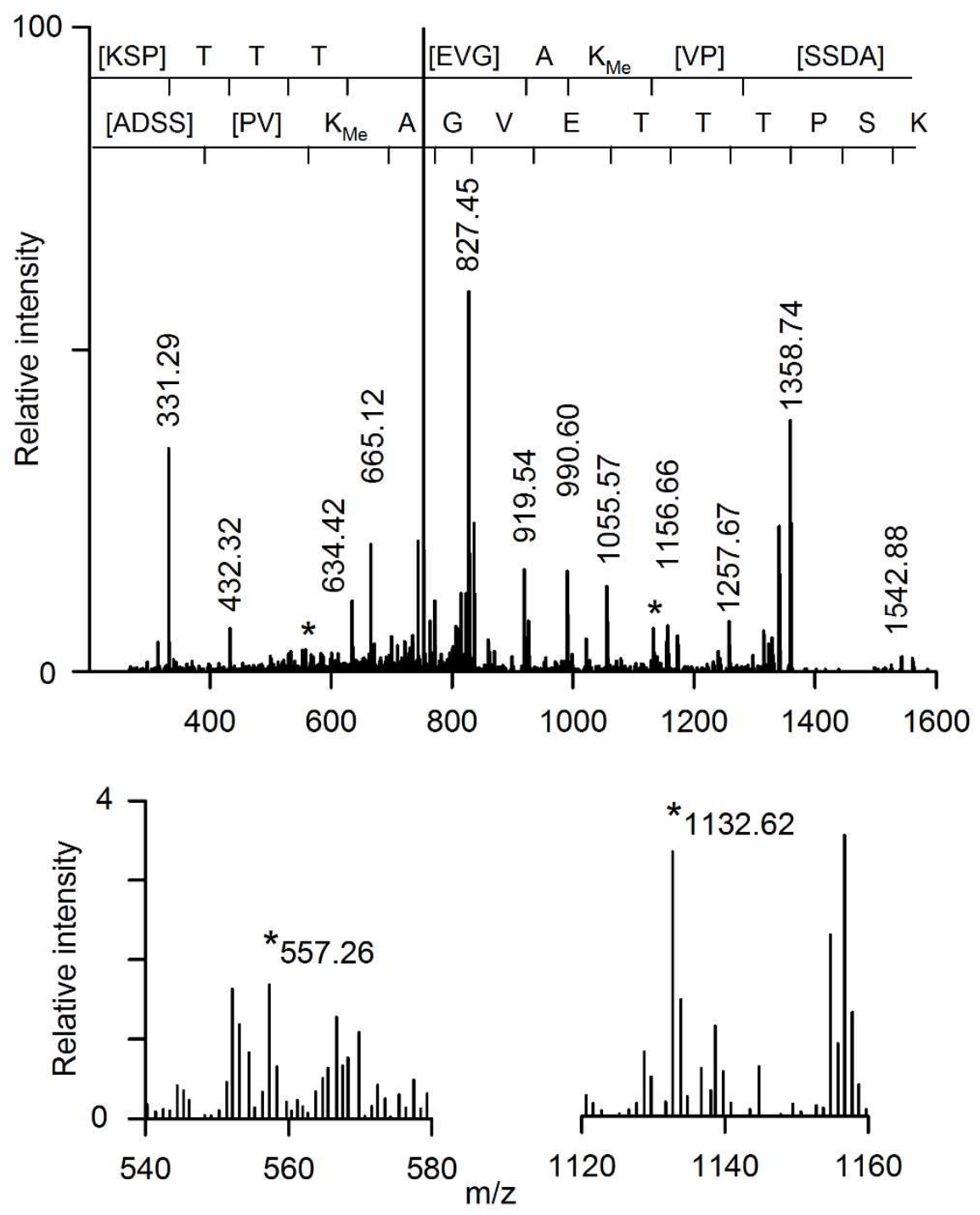
Figure 5. (A) Coverage of lambda constant region from an FFPE bone marrow sample; Mascot identified peptides are underlined. The region 44-50 (ADSSPVK) was not identified, in common with most of our lambda samples. (B) By including methyl lysine as a variable modification in the Swissprot search parameters the methylated peptide [50K $\mathrm{Me}$ ] 44-60 was identified. (C) Using an extended Uniprot + Kabat database search, the rare $\mathrm{V} \rightarrow \mathrm{I}$ variant was also identified, however examination of the mass spectra shows that this was an incorrect assignment resulting from formalin-mediated lysine methylation. The positions of the putative variant and methylated lysine are arrowed.

\begin{tabular}{|c|c|c|c|c|}
\hline \multirow[t]{3}{*}{ A } & GQPKAAPSVT & LFPPSSEELQ & ANKATLVCLI & SDFYPGAVTV \\
\hline & AWKADSSPVK & AGVETTTPSK & $\overline{Q S N N K Y A A S S}$ & YLSLTPEQWK \\
\hline & SHRSYSCQVT & $\overline{\text { HEGSTVEKTV }}$ & APTECS & \\
\hline & GQPKAAPSVT & LFPPSSEELQ & ANKATLVCLI & SDFYPGAVTV \\
\hline & AWKADSSPVK $_{\mathrm{Me}}$ & AGVETTTPSK & QSNNKYAASS & YLSLTPEQWK \\
\hline & SHRSYSCQVT & HEGSTVEKTV & APTECS & \\
\hline & $\uparrow$ & & & \\
\hline \multirow[t]{3}{*}{ C } & QPKAAPSVT & LFPPSSEELQ & ANKATLVCLI & SDFYPGAVTV \\
\hline & AWKADSSPIK & AGVETTTPSK & QSNNKYAASS & YLSLTPEQWK \\
\hline & SHRSYSCQVT & HEGSTVEKTV & APTECS & \\
\hline
\end{tabular}




\section{Supplemental data}

Mis-identification of transthyretin and immunoglobulin variants by proteomics due to methyl lysine formation in formalin-fixed paraffinembedded amyloid tissue.

Diana Canetti et al 
Table S1: Patient details for TTR control samples, non-genotyped samples and excluded samples (no WT coverage of TTR 105-127). The methylated peptide [126K $\left.\mathrm{K}_{\mathrm{Me}}\right] 105-127$ was present only in the five non-genotyped TTR samples but absent in all controls.

\begin{tabular}{|c|c|c|c|c|c|}
\hline Patient & Tissue & Gender & Age & Amyloid & Comments \\
\hline 37 & bladder (FFPE) & M & 75 & ATTR & non genotyped \\
\hline 38 & cardiac (FFPE) & M & 76 & ATTR & non genotyped \\
\hline 39 & cardiac (FFPE) & M & 87 & ATTR & non genotyped \\
\hline 40 & cardiac (FFPE) & M & 85 & ATTR & non genotyped \\
\hline 41 & GI (FFPE) & $\mathrm{F}$ & 83 & ATTR & non genotyped \\
\hline 42 & BMT (FFPE) & $\mathrm{F}$ & 67 & $\operatorname{AL}(\kappa)$ & FFPE control \\
\hline 43 & cardiac (FFPE) & $\mathrm{F}$ & 60 & $\operatorname{AL}(\kappa)$ & FFPE control \\
\hline 44 & cardiac (FFPE) & M & 64 & $\operatorname{AL}(\lambda)$ & FFPE control \\
\hline 45 & cardiac (FFPE) & M & 69 & $\operatorname{AL}(\lambda)$ & FFPE control \\
\hline 46 & cardiac (FFPE) & M & 84 & $\operatorname{AL}(\kappa)$ & FFPE control \\
\hline 47 & GI (FFPE) & M & 81 & $\mathrm{AL}(\kappa)$ & FFPE control \\
\hline 48 & GI (FFPE) & $\mathrm{F}$ & 80 & AApoA1 & FFPE control \\
\hline 49 & renal (FFPE) & M & 44 & AApoA1 & FFPE control \\
\hline 50 & renal (FFPE) & M & 51 & AFibA (E526V) & FFPE control \\
\hline 51 & renal (FFPE) & M & 60 & AFibA (E526V) & FFPE control \\
\hline 52 & renal (FFPE) & M & 71 & $\mathrm{AL}(\kappa)$ & FFPE control \\
\hline 53 & skin (FFPE) & $\mathrm{F}$ & 66 & $\operatorname{AL}(\kappa)$ & FFPE control \\
\hline 54 & cardiac (FFPE) & M & 66 & ATTR (T60A) & no WT coverage \\
\hline 55 & cardiac (FFPE) & M & 76 & ATTR (WT) & no WT coverage \\
\hline 56 & GI (FFPE) & M & 69 & ATTR (WT) & no WT coverage \\
\hline 57 & fat & $\mathrm{F}$ & 53 & $\mathrm{AL}(\lambda)$ & fat control \\
\hline 58 & fat & $\mathrm{F}$ & 58 & $\operatorname{AL}(\lambda)$ & fat control \\
\hline 59 & fat & M & 60 & $\operatorname{AL}(\lambda)$ & fat control \\
\hline 60 & fat & $\mathrm{F}$ & 65 & $\operatorname{AL}(\lambda)$ & fat control \\
\hline 61 & fat & $\mathrm{F}$ & 79 & $\operatorname{AL}(\lambda)$ & fat control \\
\hline 62 & fat & M & 67 & $\mathrm{AL}(\kappa)$ & fat control \\
\hline 63 & fat & $\mathrm{F}$ & 49 & ATTR( I73V) & no WT coverage \\
\hline 64 & fat & $\mathrm{F}$ & 72 & ATTR (V122I) & no WT coverage \\
\hline 65 & fat & M & 84 & ATTR (V122I) & no WT coverage \\
\hline
\end{tabular}


Table S2. Patients' samples used in the immunoglobulin lambda analysis study.

Samples containing the $\Delta 14$ 44-60 peptide are marked $(+)$. There was a significant level of lambda peptides present in control samples L28 and L29, and these both showed the presence of the $\Delta 14$ peptide.

\begin{tabular}{|c|c|c|c|c|c|}
\hline Patient & Gender & Age & $\begin{array}{c}\text { Amyloid } \\
\text { type }\end{array}$ & $\begin{array}{l}\text { FFPE } \\
\text { tissue }\end{array}$ & $\begin{array}{c}\Delta 14 \\
\text { peptide }\end{array}$ \\
\hline L1 & $\mathrm{M}$ & 59 & $\overline{A L}(\lambda)$ & cardiac & + \\
\hline L2 & M & 76 & $\operatorname{AL}(\lambda)$ & renal & + \\
\hline L3 & M & 51 & $\operatorname{AL}(\lambda)$ & cardiac & \\
\hline L4 & M & 75 & $\operatorname{AL}(\lambda)$ & cardiac & + \\
\hline L5 & M & 81 & $\operatorname{AL}(\lambda)$ & rectal & \\
\hline L6 & $\mathrm{F}$ & 44 & $\operatorname{AL}(\lambda)$ & cardiac & \\
\hline $\mathrm{L} 7$ & $\mathrm{M}$ & 66 & $\operatorname{AL}(\lambda)$ & cardiac & + \\
\hline L8 & M & 43 & $\operatorname{AL}(\lambda)$ & renal & \\
\hline L9 & $\mathrm{F}$ & 14 & $\operatorname{AL}(\lambda)$ & skin & + \\
\hline L10 & M & 65 & $\operatorname{AL}(\lambda)$ & cardiac & + \\
\hline L11 & $\mathrm{F}$ & 41 & $\operatorname{AL}(\lambda)$ & laryngeal & + \\
\hline L12 & M & 77 & $\operatorname{AL}(\lambda)$ & laryngeal & \\
\hline L13 & M & 84 & $\operatorname{AL}(\lambda)$ & laryngeal & + \\
\hline L14 & $\mathrm{F}$ & 79 & $\operatorname{AL}(\lambda)$ & adrenal & \\
\hline L15 & M & 51 & $\operatorname{AL}(\lambda)$ & spleen & + \\
\hline L16 & $\mathrm{F}$ & 65 & $\operatorname{AL}(\lambda)$ & laryngeal & + \\
\hline L17 & $\mathrm{F}$ & 44 & $\operatorname{AL}(\lambda)$ & laryngeal & + \\
\hline L18 & M & 78 & AFib (E526V) & renal & \\
\hline L19 & M & 68 & AFib (E526V) & renal & \\
\hline L20 & M & 74 & AFib (E526V) & renal & \\
\hline L21 & $\mathrm{F}$ & 73 & AFib (E526V) & renal & \\
\hline L22 & M & 50 & AFib (E526V) & renal & \\
\hline L23 & M & 79 & AFib (P552H) & renal & \\
\hline L24 & M & 50 & $\mathrm{AL}(\kappa)$ & skin & \\
\hline L25 & $\mathrm{F}$ & 73 & $\operatorname{AL}(\kappa)$ & renal & \\
\hline L26 & $\mathrm{F}$ & 62 & $\operatorname{AL}(\kappa)$ & renal & \\
\hline L27 & M & 63 & $\mathrm{AL}(\kappa)$ & rectal & \\
\hline L28 & M & 60 & AApoAI & $\mathrm{BMT}$ & + \\
\hline L29 & $\mathrm{F}$ & 79 & AApoAI & renal & + \\
\hline L30 & M & 68 & ATTR & laryngeal & \\
\hline L31 & M & 65 & ATTR & cardiac & \\
\hline L32 & M & 82 & ATTR & cardiac & \\
\hline
\end{tabular}


Figure S1. Full MSMS spectra for TTR peptide [122I]105-127 from the authentic V122I variant (top panel) and the $126 \mathrm{~K}_{\mathrm{Me}}$ methylated wild type peptide formed during formalin fixing(bottom panel). The spectra are essentially indistinguishable between $\mathrm{m} / \mathrm{z} 700$ and 2000.
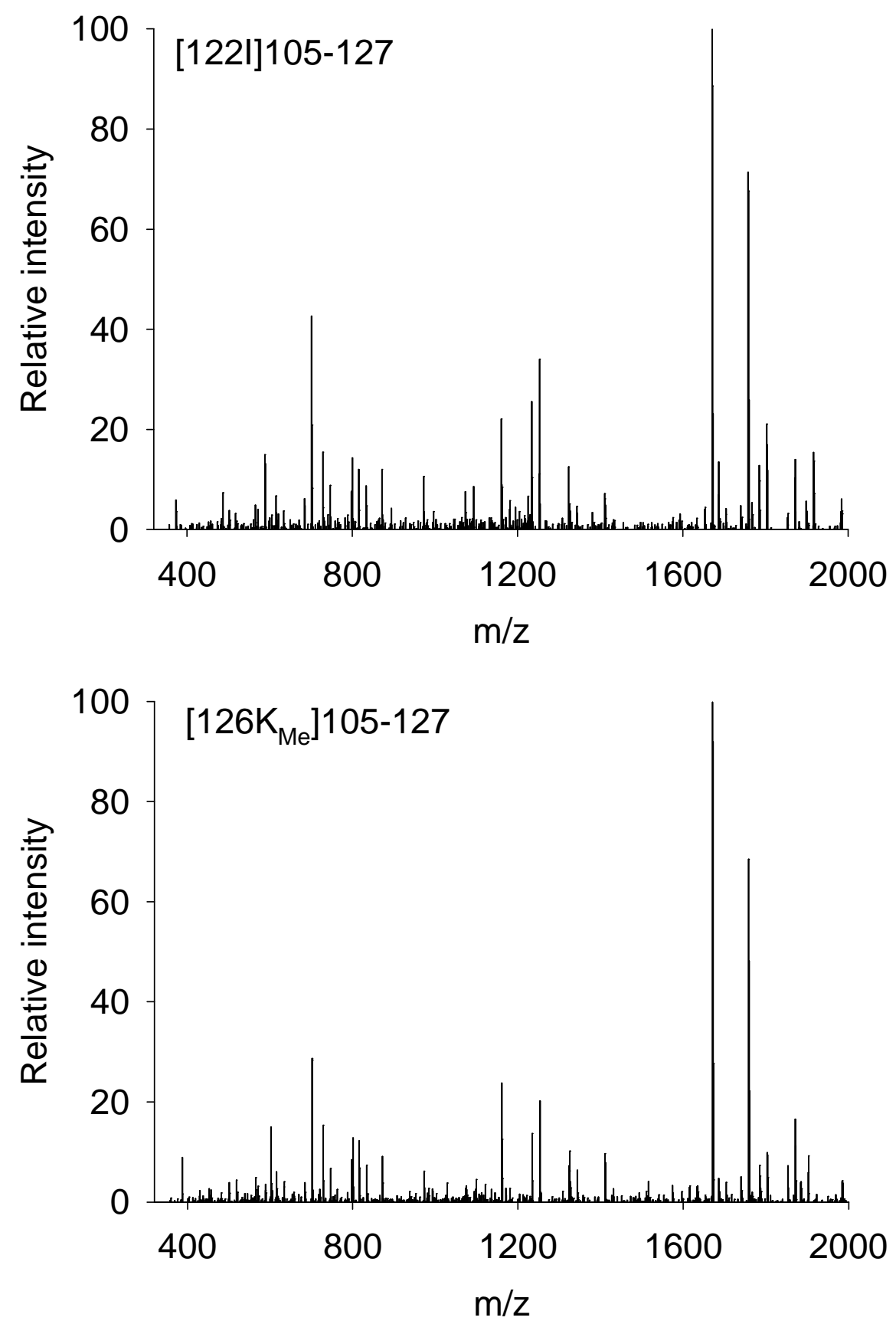
Figure S2. MSMS spectra of m/z $1688.878^{3+}$ from three digested lambda samples analysed on a Q-Exactive instrument. Sequence ions for ..K $\mathrm{Ke}_{\mathrm{Me}} \mathrm{AGVETTTPS..} \mathrm{are}$ highlighted in red. The characteristic y11 ion $(\mathrm{m} / \mathrm{z} 1132.6)$ is present in all spectra (see red asterisk).
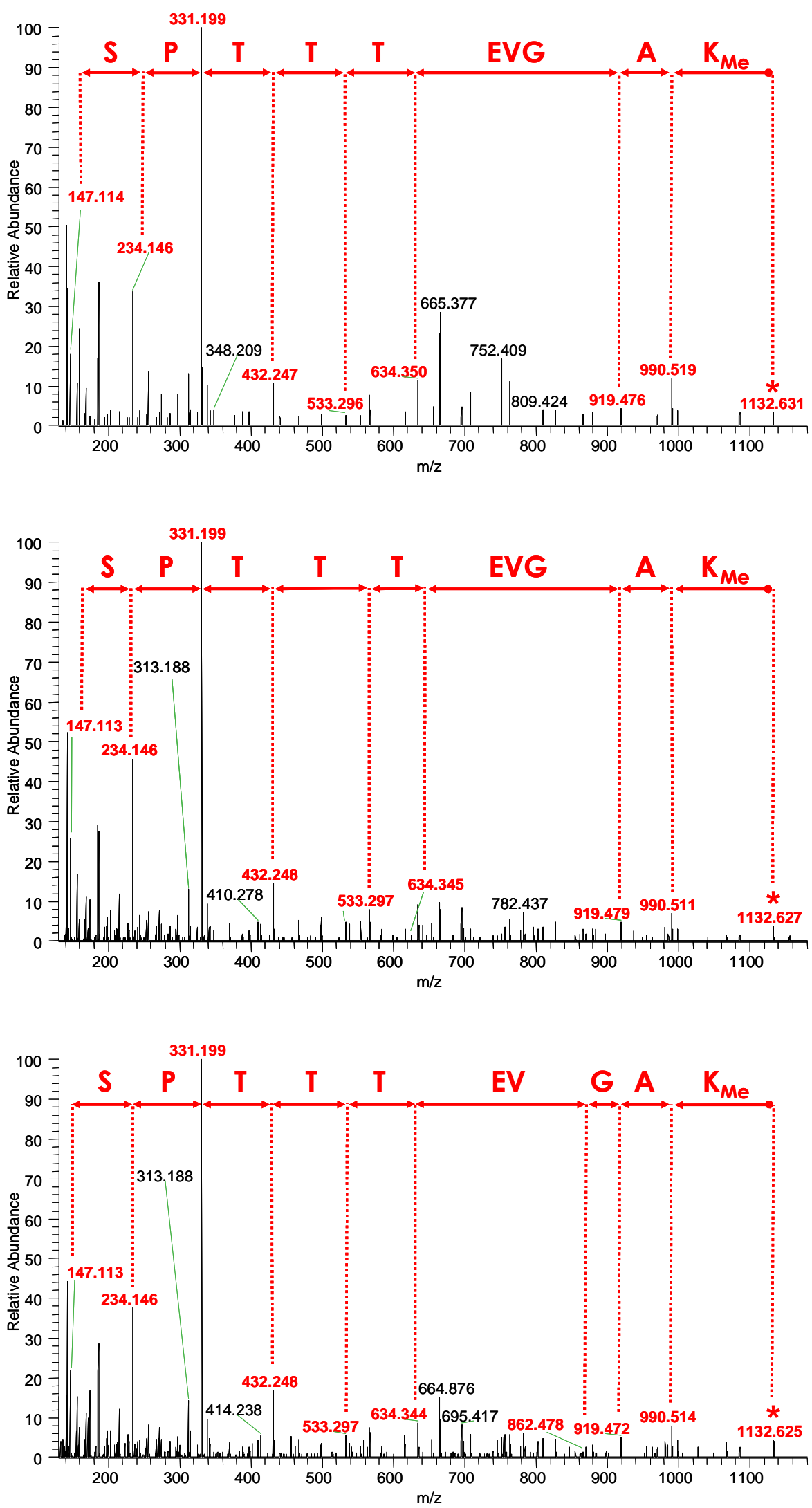